\title{
Cuerpo, trópico y tiempo: elementos de creación identitaria en la poesía de Nicolás Guillén
}

Gerardo Farías Rangel Universidad de Guanajuato

\section{Resumen}

El siguiente artículo aborda la obra del poeta cubano Nicolás Guillén, tomando como base el poemario West Indies Ltd., publicado por primera vez en 1934, además de tomar en cuenta otros poemas de su producción anterior y posterior, con la finalidad de analizar su propuesta de creación de una nueva identidad, una ontología telúrica, fundamentada en lo material, por sobre lo metafísico, como respuesta a una serie de cuestionamientos existenciales que parten desde el interior del yo lírico, el cual usa el cuerpo y su relación con el trópico, y el tiempo como base fundamental de su creación poética.

Palabras clave: Nicolás Guillén, poesía cubana, identidad, cuerpo, ontología telúrica.

\section{Abstract}

This article approaches the Cuban poet Nicolás Guillén's work focusing on the collection West Indies Ltd., first published in 1934, also taking into consideration other poems of his previous and later works, this with the aim of analyzing his proposal of creating a new identity, a telluric ontology, based on the material elements, above metaphysics, as a response to a series of existential questions originated inside the lyrical voice which takes the Body and its relations with the Tropic and the Time as the fundamental basis of the poetic creation.

Keywords: Nicolás Guillén, Cuban poetry, identity, body, telluric ontology. 
$\mathrm{I}^{\mathrm{n}}$

maginemos un escenario: el primer ser humano se despierta y se encuentra parado sobre la tierra, rodeado de palmeras y mucha vegetación, enfrente de él está el mar y su brisa le refresca el rostro. Es un lugar donde todo lo tiene a la mano: sustento y refugio. Este primer ser humano no cae en cuenta de que todo aquello que ve, escucha y toca no es parte de él. Tardará miles de años en "comprender" que hay un abismo entre los objetos que lo rodean y su conciencia, pero eso no importa ahora, porque él está ahí en medio del Trópico, simplemente siendo.

El abismo que existe entre el ser humano y su exterior es una constante inquietud del poeta, ser marginado por excelencia. Ya desde Platón, en su República, los poetas fueron vistos sospechosamente y tratados como seres despreciables y peligrosos. En la actualidad no ocurre algo tan distinto. ¿Por qué el poeta es alguien que parece no tener un lugar en este mundo? El romanticismo es uno de los movimientos literarios que trabajó muy hondamente sobre esta falta de plenitud en la vida y exaltó el descontento con la realidad. De esto, hace ya más de un siglo; sin embargo, estas posturas parecen haber sido heredadas por la poesía contemporánea y un ejemplo es la obra del poeta cubano Nicolás Guillén. ${ }^{1}$

Creo que la pregunta aplica a todo ser humano: ¿Cuál es "mi lugar en el mundo”? La poesía brinda, quizá, el camino más arriesgado hacia la respuesta de dicha cuestión. En una sociedad fragmentada, indiferente, envuelta en una burbuja de apariencias,

${ }^{1}$ Si bien es cierto que Nicolás Guillén se desprendió de varios motivos románticos en su poesía, creo que es válido argumentar que existe una presencia de ciertas actitudes románticas en su labor poética. No es mi interés principal analizar la relación entre el romanticismo y la obra del poeta cubano; sin embargo, como se verá a lo largo de este artículo, la voz guilleniana apela a la naturaleza que lo rodea para armarse de fuerzas que le permiten hacer frente a una realidad con la que se siente un desencanto, lo cual provoca un vacío, una profunda necesidad de fundar una nueva identidad. 
consumista como la nuestra, la de los siglos XX y XXI, esta "era del vacío” como sentenciara Lipovetsky, ¿qué ocurre con el individuo que no encuentra asidero en ningún sitio dentro de esa masa llamada sociedad y decide volverse poeta (o narrador o filósofo o artista)? Lo que sucede es que deja de ver el mundo exterior con ojos ajenos y mediáticos, por momentos adquiere la visión del primer hombre sobre la tierra y ve todo tal como es o como debiera ser. Entonces, el poeta se embarca en la que puede ser su única misión en la vida: transmitir ese mensaje, no transcribir en el papel lo que pasa "afuera" en el mundo, sino ser elemento creador de una realidad diferente que, en principio, sólo puede llegar a la realización en sus propios poemas. Octavio Paz insiste en que:

El poema no es el eco de la sociedad, sino que es, al mismo tiempo, su criatura y su hacedor, según ocurre con el resto de las actividades humanas. En fin, ni el Sexo, ni el Inconsciente, ni la Historia son realidades meramente externas, objetos, poderes o substancias que obran sobre nosotros. El mundo no está fuera de nosotros; ni, en rigor, dentro. Si la inspiración es una "voz" que el hombre oye en su propia conciencia, ¿no será mejor interrogar a esa conciencia, que es la única que la ha escuchado y que constituye su ámbito propio? (Paz, 2010: 165)

Esta interrogación dirigida hacia la conciencia está presente en la poesía de Nicolás Guillén. Él, como casi todos los poetas, se pregunta por la capacidad del lenguaje para transformar el mundo, no el exterior porque, como ya vimos, no hay exactamente algo "allá afuera", sino una transformación hacia y desde el interior. El poeta parece ser la única clase de hombre, o una de las pocas, que se atreve, antes que nada, a reconocer que lo que se "comprende" como externo no es tal y vive en conflicto continuo entre la concepción del mundo moderno y su inspiración, esa voz interna que le dice que las cosas son otras. Octavio Paz sostiene que el decir poético 
está siempre en una situación conflictiva que diluye la fuerza volitiva del que se expresa, y él lo dice porque se sabe poeta: "Si se ha de creer a los poetas, en el momento de la expresión hay siempre una colaboración fatal y no esperada. Esta colaboración puede darse con nuestra voluntad o sin ella, pero asume siempre la forma de una intrusión. La voz del poeta es y no es suya” (2010: 157).

¿Cómo confiar en esa voz intrusa? ¿Cómo sentir de la misma forma que el hombre primero que carecía de filtros entre su interior y lo exterior? Esta respuesta es antropológicamente imposible de contestar, no hay conocimiento científico que nos acerque a la resolución de esta cuestión. La poesía, sin embargo, ofrece un conocimiento distinto de la realidad pues "La poesía es la conciencia más fiel de las contradicciones humanas, porque es el martirio de la lucidez, del que acepta la realidad tal y como se da en el primer encuentro" (Zambrano, 2010: 62). El poeta sabe que su sino está marcado por una situación que no es aprehensible a través de los caminos de la razón, acepta la tragedia, pero está en él decidir si lamentará o cantará frente a tal destino.

Guillén, nacido en Camagüey en 1902, es reconocido por la crítica, el pueblo cubano y prácticamente toda Latinoamérica, como "Poeta nacional". Este epíteto se lo ganó a pulso por su reivindicación de la cultura negra dentro de la poesía cubana, su impulso por buscar ese "color cubano", ni negro ni blanco, y su postura consciente ante la problemática social en la que vivía. Muchos factores externos moldearon esta visión que se tiene de Nicolás Guillén: su labor periodística, su actitud antiimperialista, la constante crítica social y su militancia política. Pareciera que Guillén fue un hombre más apegado a sus circunstancias sociales, al cual le importaba más la situación de la gente de su(s) isla(s), que un hombre en crisis por una cuestión ontológica personal, un cuestionamiento íntimo de su propia existencia. 
En este análisis, exploraré cómo dicha inquietud ontológica existe y está expresada primordialmente en su poesía y de ahí se convirtió en la base de sus discursos y críticas socio-políticas. Porque antes que cualquier cosa, Guillén es y fue poeta, y en su obra es claro cómo este cuestionamiento íntimo es, a la vez, un problema social y universal. Además, ante toda circunstancia contradictoria, trágica o adversa él ha preferido cantar.

\section{Cantar desde adentro}

Desde sus primeros poemas, Nicolás Guillén dejó muy en claro lo que sería su propuesta poética: qué clase de poeta era y a qué musa le cantaría. Arriba, puntualicé que la constante interrogación con esa "voz interior" que es la inspiración, es una de las características fundamentales que marca el devenir de todo poeta. ¿A qué musa le canta Guillén, cómo concibe su "inspiración”? En su "Elegía moderna del motivo cursi", un poema de transición, esto queda explicado cuando el poeta confiesa: "Lo que ocurre es que aspiro / a eliminar el tipo de la mujer-suspiro, / que está dentro del mundo como un pájaro preso. / Por lo pronto, mi musa ya está hecha a mi modo. / Fuma. Baila. Se ríe”. La musa es algo terrenal, no proviene de un "más alla”". Ha dejado de ser una especie de espíritu divino que se posa sobre la cabeza del poeta y dicta sus versos. Ahora el poeta baila, fuma y se ríe con ella, con su inspiración, la mira de frente y lo puede hacer porque ha dejado de ser etérea, ya no es un "suspiro", sino algo material o, mejor dicho, algo carnal.

En su poema "A la nueva musa" plantea su posicionamiento poético, es decir, desde dónde canta: ya no será el poeta que, como director de orquesta, se para frente a los músicos y les dicta cómo y qué tocar para beneplácito de un público: "Ahora, el poeta se mete dentro de sí mismo / y allá adentro, dirige su orquesta”. El interior, lo íntimo y personal es la base sustancial de la poesía guilleniana. 
Esta posición poética, definida así desde sus inicios, tendrá repercusiones filosóficas en futuros poemarios, como en West Indies, $L t d$., al cual me acercaré en varios momentos.

\section{El Dios-Trópico y el cuerpo humano como elementos de creación identitaria}

El poemario West Indies, Ltd. publicado en 1934, llama la atención por su título en inglés: "West Indies", es decir, "las Indias Occidentales", las Antillas. Este nombre marca una distinción respecto a las obras escritas anteriormente (Corazón y cerebro, Motivos de son y Sóngoro cosongo); la intención de este detalle es doble. Primero, el uso de la lengua inglesa se debe a una actitud irónica que pareciera colocarse en la visión del Otro, que en este caso es el imperio americano, que se ha posicionado en Cuba y en todas las demás islas. Guillén muestra la herida y, no sólo le pone vinagre, sino también pimienta, al agregarle la palabra Limited con lo que enfatiza la idea de que este lugar no se ha vuelto más que en una compañía a la cual cierto reducido número de socios tienen acceso. La segunda intención, es de carácter espacial: el poeta ya no habla desde su isla cubana sino que su voz lírica se posiciona más allá, habla desde todas Las Antillas como un conjunto de islas hermanas que viven en el trópico. Esta expansión geográfica no contradice la intensión primordial, antes señalada, de partir desde el interior: el poeta sigue dentro de sí mismo dirigiendo su orquesta, pero dicha orquesta está hecha con todos los elementos externos. Además, la voz lírica de estos poemas está en constante búsqueda de una integración entre lo exterior y lo interior, unión de polos, de aspectos, espacios, elementos, lo cual es muy obvio en la unión de las razas negra y blanca. Sin embargo, este discurso poético va más allá de una conciliación social, busca una comunión mucho más profunda, de 
carácter ontológico, la cual tiene una gran repercusión en la forma de poetizar el cuerpo humano y, en general, todo lo material.

La colección de poemas inicia con "Palabras en el Trópico", en cuyo título se hermanan dos elementos fundamentales en la poética del autor antillano: la palabra como material primordial de la poesía y el trópico que representa un lugar identitario; ambos concebidos como espacios para crear una nueva visión de mundo. Como acto inaugural, este poema representa una suerte de Arte Poética, donde precisamente se inicia una evocación de lo que es un nuevo hombre sobre esta tierra, que se crea así mismo, al mismo tiempo que crea a su dios, el Trópico. La creación la inicia, lo que llamo aquí, el Dios-Trópico:

Trópico,

tu dura hoguera

tuesta las nubes altas

$[\ldots]$

Tú secas en la piel de los árboles

la angustia del lagarto.

Tú engrasas las ruedas de los vientos

para asustar a las palmeras.

[...]

Tú atraviesas

con una gran flecha roja

el corazón de las selvas

y la carne de los ríos. ${ }^{2}$

${ }^{2}$ Las cursivas son mías. 
En este poema los verbos muestran la forma de relación entre el nuevo hombre y su dios: el Trópico es un "tú lírico" capaz de realizar una serie de acciones que repercuten en el ambiente natural del poema. Su esencia es transformadora, ya que tuesta, seca, engrasa, asusta, atraviesa... todas éstas, acciones transitivas que provocan un cambio de estado en las cosas. Así, el Trópico no es sólo un lugar identitario, donde se encuentran Las Antillas, es también un ser creador que pone en movimiento los elementos que lo caracterizan: la "hoguera", es decir, el fuego hecho en la tierra se dirige hacia las "altas nubes", luego baja a los árboles para "secar la angustia del lagarto", y en el siguiente verso vuelve a subir con "la rueda de los vientos" que "asusta" a las palmeras. Este movimiento vertical se debe al interés ontológico de encontrar comunión entre los opuestos, en este caso, arriba y abajo, pero también en todas las demás direcciones. Sobre esto volveré al hablar de los versos finales de este poema.

Otra forma de unión fundamental para Guillén es la relación entre los elementos del trópico y el cuerpo humano. En los versos "Tú secas en la piel de los árboles / la angustia del lagarto" y "Tú atraviesas / con una gran flecha roja / el corazón de las selvas I y la carne de los ríos", hay una prosopopeya de los elementos terrenales, así como en la mayoría de los poemas de la colección. La intensión de este recurso es darle un carácter más humano a aquello que en apariencia es externo y ajeno al hombre: las selvas tienen corazón y los árboles piel, con lo que se busca crear vínculos de empatía y reconocimiento; le brinda a la naturaleza cualidades humanas sobre todo relacionadas con lo corpóreo, lo cual es una de las formas más básicas y fundamentales de reconocer una identidad. También, se encuentra la acción inversa donde el cuerpo humano se asemeja o se mimetiza con lo tropical, con lo terreno. Por ejemplo, el posicionamiento del yo lírico a un mismo nivel que las islas antillanas en la cuarta estrofa del poema: "Aquí, / en me- 
dio del mar, / retozando en las aguas con mis Antillas desnudas, / yo te saludo, Trópico". La voz enunciante comparte características espaciales y físicas con las islas y desde ese sitio saluda al Trópico, como si fuera un viejo amigo, con un saludo que se le escapa del "pulmón salado"; es decir, como si fuera un ser marino, como si en lugar de aire tuviera agua dentro de sus pulmones. Más adelante en el mismo poema, el Dios-Trópico es el que le da al yo lírico su complexión corpórea:

Puños los que me das

para rajar los cocos tal un pequeño dios colérico;

ojos los que me das

para alumbrar la sombra de mis tigres;

oído el que me das

para escuchar sobre la tierra las pezuñas lejanas

[...]

Las palabras poéticas sirven para "ver" al Trópico, reconocerlo, darle vida y poder, incluso hablar con él y saludarlo, pero, de la misma forma, el yo lírico es creado con sus palabras y por intercesión de este nuevo dios. Comparten características fundamentales ya que los dos tienen el poder de transformar su entorno: ambos son dioses transformadores. Existe una ansia en el yo lírico por unirse a ese Dios-Trópico al que no precisamente le rinde pleitesía sino que evoca y convoca a su encuentro: “iAh, / qué ansia / de aspirar el humo de tu incendio / y sentir en dos pozos amargos las axilas!". Aspirar es una forma de integrar algo externo a nuestro ser. No es cualquier cosa lo que inspira: es humo proveniente de un incendio, el de la hoguera que tuesta las altas nubes y, además, esta imagen es acompañada por un recoveco humano muy íntimo: las axilas.

Hay en este poema inaugural una constante unión de elementos de distinta índole: lo corporal con lo vegetal, lo marino con lo celestial, lo terrenal con lo divino, y muchos de ellos están en con- 
tinua permutación. Guillén logra esta unión sustancial a través de la concatenación de imágenes que se amalgaman creando nuevos sentidos. Hacia el final de "Palabras en el Trópico" se enumeran una serie de situaciones que el yo lírico agradece a su Dios-Trópico: "el cuerpo oscuro", "la sangre imborrable", "los días altos, / en cuya tela azul están pegados / soles redondos y risueños", "los labios húmedos", "la cola del jaguar y la saliva de las culebras". Todas estas imágenes se suman a las antes citadas que giraban en torno a lo corpóreo.

La imagen es centro de esta poesía ajena a cualquier intelectualismo, porque no busca la idea ni el concepto, se convoca a lo material, a lo carnal. No hay que olvidar que su "musa" es una mujer que suda, boxea, se exalta, fuma, baila y se ríe. El poeta hace esto porque le interesan la flexibilidad y la mutabilidad que brindan las imágenes, ya que trascienden las sensaciones, transforman lo concreto y lo vuelven plástico ("Las axilas, oh Trópico, / con sus vellos torcidos y retorcidos en tus llamas") y se convierten en un imaginario mucho más enriquecedor. Los versos finales del poema remarcan la intensión, que vengo comentando, de crear una unión material de lo divino con lo corporal, lo celestial y lo marítimo, y lo vertical con lo horizontal. Todo esto se logra a través de una gran serie de imágenes:

$[\ldots]$
te debo, Trópico,
este entusiasmo niño
de correr en la pista
de tu profundo cinturón lleno de rosas amarillas
riendo sobre las montańas y las nubes,
mientras un cielo marítimo
se destroza en interminables olas de estrellas a mis pies. 
Ante la crisis social y política a la que se enfrenta el poeta cubano, antes de atacar al imperialismo yanqui y denunciar con ironía el sufrimiento de la gente de Las Antillas, se preocupa primera y esencialmente por inaugurar un acto de comunión entre el hombre y su exterior. Así, muestra primero de qué está hecho este hombre antillano y con ello sustenta todos los reclamos que aparecen en los poemas sucesivos. El Dios-Trópico le brinda sus propias cualidades, le da un cuerpo con el cual obtener lo que necesita, le da un "espíritu": "este entusiasmo nińo"; y termina por rendir cielo y mar a sus pies. La palabra poética funciona al servicio de un interés íntimo y personal que se ha vuelto universal: la pertenencia a algo, una identificación con la Tierra. La imagen y la imaginación crean en los poemas guillenianos un vínculo muy fuerte con su intimidad, ya que, como señala Gaston Bachelard:

Las imágenes no son conceptos. No se aíslan en su significación. Precisamente tienden a rebasar su significación. La imaginación es entonces multifuncional [...] En efecto es posible sentir en acción, en muchas imágenes materiales de la tierra, una síntesis ambivalente que une dialécticamente el contra y el dentro y que muestra una solidaridad innegable entre los procesos de extroversión y los procesos de introversión. [...] Todas las grandes fuerzas humanas, aun cuando se despliegan de forma exterior, son imaginadas en una intimidad (Bachelard, 2006: 13).

Las cosas están más allá de las palabras, el lenguaje no permite poner ante nosotros exactamente lo que es el "mundo exterior" porque se nos escapa constantemente. Pero la poesía renueva el lenguaje, o incluso crea su propio y nuevo sistema de comunicación, a través de estas imágenes que provienen del interior. Permite acceder a un nuevo tipo de conocimiento que evite la evanescencia. Raymundo Mier dice al respecto que: "Las palabras de Guillén buscan dar nombre, tiempo, amparo a los acontecimientos 
destinados habitualmente a la desaparición, a las presencias que se disipan, que acaso se habrán de preservar en el dominio de las claves secretas de la propia identidad" (2006: 72).

La poesía de Guillén representa la inauguración de un nuevo rito identitario, un momento en el que la creación poética, a diferencia de los mitos religiosos de creación, se lleva a cabo de forma dialéctica entre hombre y dios, ya que uno no es creación unilateral del otro sino que ambos usan la palabra para evocarse y crearse mutuamente. Aunque es importante también conceder que esta experiencia poética comparte ciertos rasgos con la experiencia religiosa porque "es un salto mortal: un cambiar de naturaleza que es también un regresar a nuestra naturaleza original" (Paz, 2006: 137).

El hecho de que Guillén centre gran parte de este rito identitario en lo material y, sobre todo, en lo corporal, habla de un proceso de reivindicación del mismo cuerpo humano. Ya decía que su musa, su inspiración, se identifica más con lo corporal, con el movimiento del cuerpo a través de la danza y el boxeo, y con los placeres y vicios corporales (fumar y beber). Si la base de esta poesía se encuentra en el cuerpo, es debido a que la búsqueda aquí emprendida es hacia un origen no conceptual, un origen más inmediato, más "real". El cuerpo es la manera más directa que tiene el ser humano de identificarse, pero al mismo tiempo se ha vuelto objeto de control. Michel Foucault hablaba de una anatomía politica a través de la cual existe sobre el cuerpo "una manipulación calculada de sus elementos, de sus gestos, de sus comportamientos. El cuerpo humano entra en un mecanismo de poder que lo explora, lo desarticula, lo recompone" (2010: 159). Nicolás Guillén está interesado en la manipulación del cuerpo pero no con intenciones de control sino con una finalidad creativa que logre romper con una dinámica de poder aplicada sobre el mulato, el negro, la gente antillana; es decir, el ser humano colonizado. 
A partir de estas posturas, es posible señalar la presencia de ciertos rasgos de performatividad en la poesía guilleniana. Para Judith Butler el cuerpo representa uno de los elementos de la sociedad humana sobre el cual se ha generado una mayor cantidad de discursos de control; esto, por supuesto, siguiendo los análisis del ya mencionado Foucault y muchos otros teóricos relacionados con la emancipación del sujeto. Cuando digo que hay performatividad en el uso de lo corpóreo en la poesía de Guillen no estoy diciendo que exista un discurso de control sobre éste, sino que a partir de un nuevo discurso se está generando una "práctica reiterativa y referencial mediante la cual el discurso produce los efectos que nombra" (2010: 18). Para Butler eso es performatividad; es decir, existe un nombramiento de un nuevo tipo de comunión entre el cuerpo humano y la naturaleza que le rodea, lo cual tiene la capacidad de crear algo en el momento en que es descrito: lo dicho, lo nombrado, existe y puede producir efectos en quien lo lee.

En el libro Cuerpos que importan (2010), Butler analiza y desarrolla una serie de cuestiones que giran en torno a la reformulación de la materialidad del cuerpo con la finalidad de apuntar los límites materiales y discursivos del sexo. En el caso del poeta cubano hay una reformulación de la materialidad del cuerpo con una finalidad de creación identitaria. El sexo está presente, pero no es la finalidad principal, lo que quiere hacer el poeta es generar un poder performativo capaz de liberar al oprimido, en este caso, a la gente de Las Antillas. Quiere empoderar su cuerpo, ése que ha sido objeto de control a lo largo de la historia del pueblo cubano y de sus antecesores, su último resquicio de identidad, para darle la oportunidad de sentirse un dios creador capaz de modificar su relación con el exterior e ir más allá de su realidad inmediata.

Sobre este tema seguiré desarrollando más ideas con relación al tiempo y cerca del final apuntaré un término nuevo para identificar este proceso en el que el poeta cubano ha logrado hacer del 
cuerpo uno de sus materiales poéticos fundamentales para la creación de una ontología telúrica: la palabra-cuerpo.

\section{El tiempo como constante presencia creadora y su relación con lo corporal}

¿Hay en esta poética un regreso en el tiempo? La respuesta es un contundente no, lo que presenciamos aquí es la creación de un nuevo tiempo siempre presente y en movimiento. Guillermo Sucre dice que: "Uno de los rasgos dominantes en la literatura contemporánea [hispanoamericana] es el debate con y contra el tiempo", y al hablar de la poesía de Darío, Neruda, Vallejo y otros, añade que: "en casi todos esos poetas, el tiempo se presenta como una fuerza corruptora y destructiva” (2001: 336). Este no es el caso de la poesía de West Indies, $L t d$. porque lo que resulta destructivo, en todo caso, son las "companies y trusts", "los ports docks, los ferry boats, los ten cents" que aparecen en el poema que da título al libro y representan el capitalismo americano que ha llegado para quedarse y cambiar el ritmo de vida de las islas y provocar el empobrecimiento de la gente. Pero también es el hambre, “¡Hambre de las Antillas, / dolor de las ingenuas Indias Occidentales!", la que ocasiona estragos en los "hombres perdidos" que habitan este lugar porque, dice el poeta: "Nos come el hambre día a día, / y van cavándonos los dientes / charcos bermejos en la encía”. O también es la actitud del negro limosnero en el poema "Sabás" que pide pan con la mano abierta y no sabe reconocer lo que el DiosTrópico le brinda: "El cielo abriga" y "El sol calienta". Todos estos tipos de estragos no son de otra naturaleza más que corporales, el dolor físico está presente constantemente; sin embargo, trasciende su estatus material y logra quebrantar el espíritu: "Así andamos por la ciudad, / como perros abandonados / en medio de una tempes- 
tad", es el estribillo que aparece cuatro veces en "Canción de los hombres tristes".

Guillén da cuenta de los procesos de control que se han generado sobre el cuerpo de la gente que vive en Las Antillas, y lo hace para, sobre ello, seguir proponiendo un discurso de empoderamiento. El contraste entre el cuerpo poderoso del primer hombre, en el poema que abre la colección, contra el sufrimiento corporal de los personajes que aparecen a lo largo de varios de los siguientes poemas crea una especie de tensión que se resuelve de forma más esperanzadora hacia el final del poemario; sin embargo, a lo largo de cada poema se busca continuamente que el cuerpo sea la base de una especie de canto libertario ante la desolación de las contrariedades sufridas.

El tiempo no importa como concepto trascendental, lo que se resalta, en contraste, es el sufrimiento de la carne ante la imposibilidad de un "verdadero progreso". Se apuesta aquí a borrar los estadios del tiempo como cosas separadas: pasado, presente y futuro. Todos acuden a la enunciación poética para tratar de resolver la crisis ontológica que en estos poemas se siente a flor de piel, directamente en la carne, ya que:

El poeta siente la angustia de la carne, su ceniza, antes y más que los que quieren aniquilarla. El poeta no quiere aniquilar nada, nada sobre todo, de las cosas que el hombre no ha hecho. Rebelde ante las cosas que son hechura humana; es humilde, reverente, con lo que encuentra ante sí y que él no puede desmontar: con la vida y sus misterios. [...] El poeta vive según la carne, y más aún, dentro de ella. Pero, la penetra poco a poco; va entrando en su interior, va haciéndose dueño de sus secretos y al hacerla transparente, [...] la conquista para el hombre, porque la ensimisma, la hace dejar de ser extraña (Zambrano, 2010: 62). 
Guillén hace que el pasado venga al presente para fundir ambas temporalidades como en el poema "Balada de los dos abuelos" donde el pasado blanco y el pasado negro se unen en el yo lírico. Los rasgos físicos relacionados con el cuerpo (pieles "blanca y negra", "cuello ancho", "pie desnudo, torso pétreo", "venas y ojos entreabiertos", "fuertes cabezas") serán los elementos más relevantes para marcar la diferencia y crear, al mismo tiempo, la unión entre opuestos. Estamos de nuevo frente a un acto de unión donde hay, a la vez, una nueva creación, así como en "Palabras en el Trópico", porque "convocar es crear: se convoca al negro y al blanco para crear una mezcla, para que de la diferencia nazca la identidad y que los opuestos se vuelvan complementarios" (Sustaita, 2006: 58). Pero en este caso, la creación no es "divina" sino de carácter genealógico, en la cual se coloca enfrente uno del otro el antepasado español y el africano, para que dialoguen. El yo lírico da nombre, raza, origen geográfico y características personales a sus dos abuelos, lo cual resalta sus diferencias. Sin embargo, a fin de cuentas, no son más que "sombras" que sólo él ve. Lo que importa, en realidad, es la comunión y la disolución de dichas diferencias, lo cual se da a través de un acto corporal de suma relevancia: un abrazo. En "El abuelo", por otro lado, la presencia del antepasado africano se encuentra en el fondo del ser de una mujer blanca que ignora o se niega a reconocer dicha presencia en su sangre, a pesar de los rizos existentes en su "cabeza amarilla". El tiempo, en este caso el pasado, no es causante de la fragmentación o del desgaste del ser humano, el problema es la actitud de no reconocimiento, de no saberse hecho de este pasado, de negarse a convocarlo, y no ver en el cuerpo esta presencia ancestral.

La poesía de Guillén explora [la] multiplicidad del tiempo, pero funde la experiencia de la extrañeza temporal con el arraigo en el ámbito de lo inmediato; en su alianza entre juego, mímesis, alegoría, historia y metáfora se multiplican los sentidos de la experien- 
cia ordinaria: transita de los nombres de las presencias evidentes, de lo visible, de lo habitual, para trasladarse a la recuperación del mito; hace de la palabra una vía iniciática hacia la revelación de lo vivido, recobra la memoria más allá de la condena, alude a la nostalgia para restaurar la plenitud del presente (Mier, 2006: 72).

El futuro, así como el pasado, es también convocado por la voz lírica. Las lamentaciones, las críticas, los enojos y las ironías de varios de los poemas guillenianos apuntan hacia ese futuro. La "voz interna” en crisis ontológica del poeta no sólo se cuestiona por su origen y su presencia en un "ahora”, se pregunta también por una situación por venir, por suceder, o mejor aún, por ser creada. Le interesa escarbar en la tierra sobre la que pisa, explorar y analizar los objetos que están a su alcance para acusar un "extravío" porque "las palabras del poeta, flechas lanzadas hacia el territorio de lo invisible, hacia afuera de la casa que habita el hombre y que ha recibido el nombre de mundo, tienen mucho del otro" y más adelante, Antonio Sustaita continúa diciendo que esas "flechas-las-palabras" son dirigidas con fuerza, a raíz de la insatisfacción con el mundo presente, hacia "un blanco que es inconocible [sic]" (Sustaita, 2006: 56). Ese blanco, como la hoja blanca en espera de la palabra, es un destino, es el futuro. Guillén no comprende el tiempo como un suceso de eventos lineales sino como algo presente en todas partes, algo que nos rodea, y cuya naturaleza es siempre ambivalente: trágica y esperanzadora al unísono.

Si la naturaleza del porvenir es benéfica o maligna, recae, sobre todo, en las propias manos del ser humano, en lo que haga o deje de hacer con su cuerpo, ya que tiene sus "puños" de "dios colérico" que pueden "rajar los cocos" o del Dios-Trópico las "manos rudas" que pueden "partir bárbaramente las semillas / y halar de ellas el árbol opulento, / árbol recién nacido, pero apto / para echar a correr por entre los bosques clamorosos". 
No hay un futuro estático colocado "allá adelante", es un "blanco extraviado" al que sólo con las palabras poéticas se puede apuntar: sólo se le puede aprehender con las que llamo aquí palabrascuerpo, ya que al contrario de la idea platónica donde el cuerpo es una especie de cárcel para el alma, en Guillén el cuerpo es el puente único de comunión con todo aquello que transcurre en el tiempo y espacio: "Y es que la poesía ha sido en todo tiempo, vivir según la carne. Ha sido el pecado de la carne hecho palabra, eternizado en la expresión, objetivado" (Zambrano, 2010: 47-59). En la poesía del cubano, cabe resaltar, no hay dicho pecado, en todo caso hay un desinterés, como señalaba, del conocimiento intelectual, de un logos. En este Tiempo poético que inaugura Guillén lo que causa una verdadera transformación es el eros del cuerpo; el empoderamiento de éste donde el discurso poético no disecciona y controla el cuerpo humano con fines de sumisión sino que, al contrario, le brinda amplias capacidades de transformación y generación de una nueva posibilidad de existencia.

El cuerpo con su materia, con sus deseos, con sus sexos, con su poder erótico se ha vuelto una de las mejores herramientas de liberación que ha encontrado el poeta. Las palabras que Guillermo Sucre utiliza para describir el erotismo en la poesía de Juan Liscano se ajustan muy bien a la poesía guilleniana en este aspecto: "la pasión erótica encuentra su lenguaje en ciertas imágenes míticas o primordiales de principio de mundo: [...] ventiscas y tempestades, ritos solares, surgimiento del fuego; en fin la continua transmutación de una materia universal" (2001: 351).

Guillén sugiere un viaje hacia el origen, pero no hacia el primer origen bíblico o antropológico, sino hacia un origen del todo nuevo, un origen creado con base en un cuerpo que se transforma en naturaleza y se apropia de ella a través de un acto de comunión y, al final, ese cuerpo se hace palabra poética ya no para describir a un hombre antillano sino para hurgar dentro de las inquietudes 
existenciales humanas universales y atemporales. El cuerpo poético aquí presentado apuesta a la continua transmutación para transformar incluso el tiempo: la "fuerza-inspiración" del Dios-Trópico presente en el yo lírico le da la cualidad de ver Pasado y Futuro como un solo Presente.

Todo depende de la actitud en "el presente", de la visión que el individuo tenga del tiempo y su posibilidad de entrar en comunión con él. Anteriormente, cité una serie de versos donde el cuerpo sufre y el tiempo no ejerce una acción transgresora, dichas situaciones trágicas están presentes a todo lo largo del poema "West Indies, Ltd.". Sin embargo, al final del poema se da una actitud contrastante y hay, en cambio, un canto de esperanza: "Un claro, un claro y vivo / son de esperanza estalla en tierra y océano". Este canto en forma de son no puede provenir de otro lado que de la inspiración del yo-poético-dios-colérico y ha encontrado, a raíz de la unión de los opuestos y después de largas quejas y lamentaciones, ese aliento de esperanza, el cual terminará por crear una de las imágenes más inspiradoras y poéticas, probablemente, de todo el poemario. Una frase escrita en presente de indicativo que representa una flecha, dirigida al "corazón de las selvas", que no puede apuntar a otro lugar más que hacia el futuro: "El sol habla de bosques con las verdes semillas...”. El sol es la energía vital de la vida, el generador de movimiento y dirige su palabra a las semillas para que empiecen a sońar en ser árboles, de la misma forma en que el Dios-Trópico le transmitió su fuerza y poder al yo lírico en su cuerpo para que creciera a lo largo de sus poemas y cantara las tragedias del presente, convocando el pasado y, sobre todo, apuntando hacia un futuro más esperanzador.

En otro "poema de transición", anterior a West Indies, Ltd., esta actitud frente al tiempo, de constante ambigüedad, queda claramente expuesta: 
Me gustan ciertas horas, como las 3 menos cuarto, porque el reloj parece que tiene una actitud fraterna, acogedora, como si fuera a darnos un abrazo.

El tiempo, así, es un Cristo en agonía que por la herida del costado va desangrándose sutilmente entre el Futuro y el Pasado.

El poema "Reloj" pone en escena dos actitudes opuestas producto de una misma imagen: la de las manecillas del reloj. Hay un abrazo acogedor y fraterno en oposición a la agonía presente en la herida de Cristo sacrificado por los hombres. Ambos actos incumben al cuerpo: con los "brazos" del reloj el yo lírico evoca tanto un posible abrazo como un cuerpo crucificado. El cuerpo es, al mismo tiempo, referencia de afecto y de sufrimiento. Este tipo de dicotomías que se oponen, como he venido argumentando, están presentes en casi toda la poesía de Guillén, en distintas formas y características (espaciales, materiales, actitudinales, etc.), pero siempre en constante relación con lo corporal.

Ambas visiones, la fraternal y la lacerante, son convocadas para crear algo nuevo. En este sentido, aquí tenemos algo de influencia surrealista: ese acto "mágico" del conde de Lautréamont de colocar un paraguas y una máquina de coser sobre una mesa de disección, tan explotado por los seguidores y discípulos de André Bretón. Sí, el recurso es muy similar; sin embargo, esta puesta en escena no es arbitraria ni mucho menos espontánea o automática. Existe una intención y un sentido, un discurso muy definido, detrás de esta imagen: una visión casi mítica del tiempo.

He dicho que nos encontrábamos frente a la inauguración de un nuevo ritual, un nuevo mito de fundación de características muy cercanas a la experiencia religiosa, ya que, además de la presencia 
de una dialéctica entre lo humano y lo divino, la comprensión de un tiempo casi estático, circular, o más bien, en constante vaivén, es característico también de ciertos rituales religiosos. Hay en estos poemas una revalorización de un nuevo retorno, cambio aquí el adjetivo eterno de Mircea Eliade porque no parece que Guillén esté buscando un regreso a lo primitivo, al primer origen sino a lo esencial. No hay una negación de la historia sino una reflexión, una pausa que apunta hacia esa voz interna que siempre acompańa a todo ser, no es una postura contra el tiempo sino que se es tiempo. En palabras de Guillermo Sucre, cuando resalta esta característica también presente en los poetas españoles de la generación del 27, se lee así:

Y vivir el tiempo como presente ¿no implica alcanzar el grado más alto de intensidad temporal? ¿No supone también resolver la dualidad subyacente en la concepción machadiana? ${ }^{3}$ [...] Vivir el tiempo como presente, en verdad, es ya no estar en el tiempo, como si este fuese ajeno a nosotros, sino ser tiempo mismo (Sucre, 2001: 334).

La visión de tiempo guilleniana es revolucionaria en muchos sentidos; pertenece a las vanguardias, sobre todo, al estilo cubista, pues presenta en sus imágenes distintas perspectivas espaciales, temporales, geográficas, raciales unificadas en ese ser presente y, al mismo tiempo, dicha visión temporal y poética está anclada en la tradición, mantiene cierta actitud romántica y conoce las formas del verso tradicional y de arte mayor. Guillén utiliza técnicas innovadoras pero su material es terrenal y personal; usa jitanjáforas

${ }^{3}$ Guillermo Sucre se refiere a la ambigüedad de la poesía de Antonio Machado porque "vivía en el tiempo, pero no en el presente", y subraya el hecho de que "todo lo que no estaba en su noción, estaba fuera de todo tiempo, en una intemporalidad vacía; todo lo que no participaba de $s u$ emoción, derivaba en frialdad intelectual" (Sucre, 2001: 333-335). 
para devolverle su esencia mística a la palabra como en "Sensemayá" y tantos otros poemas anteriores donde se alude a rituales de brujería; visita lugares desiertos y los llena de elementos oníricos como en "Nocturno en los muelles" para hablar de la "tormentosa pesadilla" de los hombres, los cuales sólo pueden encontrar esperanza si se atreven a sońar: "Sueńan acaso / y aquí estalla el espíritu inconforme", confiesa el yo lírico desde un lugar donde el tiempo parece no pasar y esto crea una tensa atmosfera de estancamiento. También se sitúa en una escena eterna que pareciera no llegar a ningún lugar en su poema "Caminando", donde el yo lírico no tiene un destino ni una meta, simplemente va repitiendo una acción, un paso delante del otro, "Caminando, caminando, caminando...”. Helena Beristáin opina, al respecto de esta visión, que Nicolás Guillén

es un poeta fundador, inventor de una nueva modalidad de vanguardia que involucra la innovación del significante y del significado. Es un creador de textos de inmenso lirismo que, a la vez, están semióticamente enmarcados en la específica circunstancia histórica de su tiempo. En efecto, en ellos aparece constantemente inmiscuido el contexto, ya que siempre se combinan sus experiencias de introversión y de extroversión, porque no le interesan sólo la estructura y la índole de su propio espíritu, sino a la vez, [...] la organización sociocultural, política y económica, implicadas en la relación con el otro (Beristáin, 2006: 14-15).

Es un poeta al que le interesa, entonces, tener una visión del mundo amplia y personalísima a la vez. Guillén parece tener un lente gran angular y uno macro - como se dice en fotografía - que le permite mantener un diálogo constante y dirigido entre lo externo y lo interno, acercándose y alejándose, y esto abona a esa ontología telúrica de la que he estado hablando. En el quehacer poético del cubano las inquietudes íntimas se vuelven sociales, el cuerpo es 
sitio de conjunción y conjuración eróticas, es decir, se unen todos los elementos, los tiempos, la naturaleza, y se evocan los sufrimientos y las esperanzas, las tragedias y las posibilidades de los seres humanos para crear.

La interrogación del poeta por su origen racial se transforma en una lucha por los derechos humanos de igualdad. Su inquietud por la unión con lo natural crea una nueva relación "religiosa” entre lo humano y lo terrenal. Hace suya, también, una duda filosófica; pero, sobre todo, puramente humana, sobre el lugar en el mundo de cada persona. Su interés por lo corporal sabotea una metafísica que se ha encargado de vigilar y castigar los usos del cuerpo y que resulta ya innecesaria para el hombre moderno, el cual ha descuidado tanto su corporeidad en aras del conocimiento científico y el progreso técnico. Todo esto con la finalidad de generar y proponer un nuevo erotismo que es la actualización de un ritual cosmogónico que tiene como ser creador y ser creado al mismo yo lírico, que no es otro que el nuevo hombre sobre la tierra.

El cuerpo como cuerpo (y emblema) de otro cuerpo más vasto, el instante como presencia (y resumen) del tiempo: ambos constituyen una sabiduría y una mística. Una sabiduría [...] que no es un estado intelectual sino la disciplina de una experiencia: una mística que, por su parte, quiere fundar las relaciones con el hombre y el universo sobre bases no espirituales o espiritualizantes, sino materiales (Sucre, 2001: 341).

\section{A manera de conclusión}

La poesía de Nicolás Guillén es renovadora por una larga serie de elementos. Por un lado, se caracteriza por un diálogo constante con la tradición y la vanguardia, lo cual se puede apreciar en todas las variaciones de métrica que realiza, los juegos con el lenguaje, la reintegración de lo oral en la poesía, lo que lo hace un poeta 
conocedor y muy bien adiestrado en el empleo de las técnicas. Por otro lado, se le ha seńalado como un "poeta comprometido" por su intensa defensa y constante preocupación por los problemas sociales y políticos en su patria durante la época que le tocó vivir.

Sin embargo, como he intentado desarrollar en este artículo, hay algo más profundo detrás de esa innovación técnica y ese compromiso militante, algo a lo que Nicolás Guillén está constantemente regresando a lo largo de toda su poesía: una situación existencial marcada por la pertenencia y la integración.

Pertenencia a un lugar, que no es un locus amoenus, sino un lugar en conflicto, en crisis continua $-y$ no lo digo de manera negativa - pues es un lugar de choque, de constante encuentro que, a veces, resulta muy creativo y otras destructivo, lleno de desconsuelo, pobreza y dolor pero que, al mismo tiempo, irradia vida, alegría, son y canto, sustento y abrigo, y, sobre todo, esperanza.

Integración de los opuestos para contrastarlos en un inicio, pero con la meta final de unirlos, hermanarlos, crear una comunión, a la que el poeta llega a través de la evocación, de la magia, del juego con el lenguaje y el cuerpo. Un cuerpo que es maleable, pues está hecho de "arcilla" y el cual toma cualquier forma terrenal para hacerse más fuerte, más resistente; o también, se deja maltratar y pasar hambre para denunciar los atropellos del mundo moderno y vacío, falto de generosidad. Es un cuerpo al servicio de las pasiones humanas, es un cuerpo multiforme que crea un diálogo muy enriquecedor con lo material y con lo espiritual. Todo en búsqueda de una identidad. Cité a Antonio Sustaita respecto a su concepto de "flechas-palabras" para ejemplificar la forma en que la palabra poética de Guillén se dirigía hacia lo futuro y ante ese término he propuesto otro: el cuerpo-palabra; ya que es lo corporal, a través de sus distintas manifestaciones, lo que permite la creación identitaria:

Cuando la palabra se convierte en una forma de vida y de muerte, cuando los extremos se tocan, entonces la identidad se divide: de 
la herida nace el otro. El otro es la palabra de lo mismo sólo que distanciada ya del mundo; la palabra se vuelve puente, golpe que despierta para trastocar la identidad; la identidad se vuelve relación amorosa de dos opuestos, metáfora (Sánchez, 2006: 177).

El Dios-Trópico le da su cuerpo al yo lírico y éste, a través de su palabra, crea una naturaleza llena de cualidades humanas. El cuerpo es lugar de comunión del pasado, presente y futuro, en él Guillén hace revivir al antepasado y apunta hacia distintas direcciones para encontrar posibles rumbos. El cuerpo sufre de hambre y explotación para elevar la palabra poética a un grito de lamentación y crítica; la palabra se transforma y juega con sus formas y sonidos, así como el cuerpo del yo lírico transmuta en naturaleza. En fin, la palabra poética de Guillén se transforma en cuerpo y los cuerpos nombrados se transforman en palabras poéticas.

Qué mejor representación de una "forma de vida y de muerte" es sino el cuerpo. De qué otro tipo de "herida" nace más vida, "nace el otro", que de la unión de cuerpos humanos en el sexo, el cual es fruto y fuente, como la Diosa Negra evocada en el poema "Mujer nueva" y los caimitos "morados como el sexo de las negras" que trae el Dios-Trópico en su cesta. Qué mejor puente que los brazos que pueden envolver a otro cuerpo en un abrazo o sostenerlo clavado sobre un madero crucificándolo. Qué mejor puente que las piernas que "caminando, caminando, caminando..." le permiten a uno recorrer esta tierra. Qué mejor puente que los ojos y oídos para dejar entrar lo que está "allá afuera". Qué mejor "golpe” que el del hambre para "trastocar la identidad": la pregunta ¿quién soy? se desvanece cuando "La tripa impertinente hipa”. Qué mejor relación amorosa que la de "Dos nińos", uno negro y otro blanco, que son "ramas de un mismo árbol" y que, aunque éste sea de miseria, unidos lo compartan. Qué mejor metáfora de la identidad creadora que la del primer hombre sobre la tierra platicando de 
"tú a tú" con el Dios-Trópico a través de la palabra poética que se transmuta en cuerpo.

\section{Bibliografía}

Bachelard, Gaston, 2006, La tierra y las ensoñaciones del reposo. Ensayo sobre las imágenes de la intimidad, Rafael Segovia (trad.), México, FCE.

Beristáin, Helena, 2006, "La paloma retórica en el vuelo estilístico de la poesía de Nicolás Guillén", en Homenaje a Nicolás Guillén, José Luis Martínez Morales (coord.), Xalapa, Universidad Veracruzana, pp. 13-33.

Butler, Judith, 2010, Cuerpos que importan: sobre los limites materiales y discursivos del "sexo", 2a ed., Aixira Bixio (trad.), Buenos Aires, Paidós.

Eliade, Mircea, 2008, El mito del eterno retorno. Arquetipos y repetición, Ricardo Anaya (trad.), Madrid, Alianza Editorial / Emecé.

Foucault, Michel, 2010, Vigilar y castigar. Nacimiento de la prisión, $2^{\mathrm{a}}$ ed., México, Siglo XXI.

Guillén, Nicolás, 2002, Donde nacen las aguas. Antología, Nicolás Hernández Guillén y Norberto Codina (comps.), Roberto Fernández Retamar (intro.), Jorge Luis Arcos (pról.), México, FCE.

Mier, Raymundo, 2006, "La huella del vuelo o dibujo de una ausencia", Homenaje a Nicolás Guillén, José Luis Martínez Morales (coord.), Xalapa, Universidad Veracruzana, pp. 65-84.

Paz, Octavio, 2010, El arco y la lira, $3^{a}$ ed., México, FCE.

Sánchez Martínez, José Alberto, 2006, "La identidad: el dibujo de una transición”, en José Luis Martínez Morales (coord.), Homenaje a Nicolás Guillén, Xalapa, Universidad Veracruzana, pp. 175-184. 
Sucre, Guillermo, 2001, La máscara, la transparencia. Ensayos sobre poesía hispanoamericana, 2a ed., México, FCE.

Sustaita, Antonio, 2006, "La huella del vuelo o dibujo de una ausencia”, en José Luis Martínez Morales (coord.), Homenaje a Nicolás Guillén, Xalapa, Universidad Veracruzana, pp. 55-63.

Zambrano, María, 2010, Filosofía y poesía, 4a ed., México, FCE. 
